\title{
Effects of Acute and Chronic Nitrite Exposure on Rabbitfish Siganus rivulatus Growth, Hematological Parameters, and Gill Histology
}

Patrick Saoud I*, Naamani $\mathrm{S}^{2}$, Ghanawi $\mathrm{J}^{1}$ and Nasser $\mathrm{N}^{1}$

${ }^{1}$ Department of Biology, American University of Beirut, Lebanon

${ }^{2}$ Department of Biology, Beirut Arab University, Beirut, Lebanon

\begin{abstract}
Nitrite is toxic to fishes and is often encountered in recirculation aquaculture systems. Accordingly, the nitrite tolerance of potential aquaculture candidates needs to be assessed before the fish can be farmed in land-based recirculation systems. In the present work, we studied the susceptibility of the marbled rabbitfish Siganus rivulatus to nitrite. In the first experiment, we placed fish at 0,40,50,60,70, 80, 90, 100, 110, 120 and $130 \mathrm{mg} \mathrm{l}^{-1} \mathrm{NO}_{2}-\mathrm{N}$ and evaluated $96 \mathrm{~h} \mathrm{LC}_{50}$. In the second experiment we measured survival and growth of fish reared at 0, 10, 20, 30, 40 , and $50 \mathrm{mg} \mathrm{l}^{-1} \mathrm{NO}_{2}-\mathrm{N}$ for eight weeks. Blood parameters of fish in the various treatments were also measured and gill histology studied. Finally, methemoglobinemia in fish reared at various nitrite conditions was assessed. The $\mathrm{NO}_{2}-\mathrm{N} 96 \mathrm{~h} \mathrm{LC}_{50}$ of $\mathrm{S}$. rivulatus juveniles was $105 \mathrm{mg} \mathrm{l}^{-1}$. In the growth experiment, fish mortality was greater than in the control at $\mathrm{NO}_{2}-\mathrm{N}$ concentrations $30 \mathrm{mg} \mathrm{l}^{-1}$ and greater. Growth in all treatments was less than in the control but there were no significant differences among treatments. Aqueous nitrite affected various hematological parameters such as hematocrit and total hemoglobin. Compared to other aquacultured marine fishes, the marbled rabbitfish is considered tolerant to environmental nitrite.
\end{abstract}

Keywords: Rabbitfish; Siganus rivulatus; Nitrite; Methemoglobin

\section{Introduction}

As locations suitable for aquaculture become scarcer and more costly and diseases more prevalent, modern aquaculture facilities are opting for intensive and biosecure rearing systems, mostly Recirculation Aquaculture Systems (RAS). Intensive aquaculture could provide greater economic profits but intensification of fish culture frequently leads to increased loads of nitrogenous and other toxic metabolites, resulting in water quality deterioration. One of the toxic nitrogenous wastes often encountered in aquaculture systems is nitrite $\left(\mathrm{NO}_{2}{ }^{-}\right)$which often reaches toxic levels in intensive RAS $[1,2]$. In most intensive marine fish tank culture, some nitrite is tolerated as it is difficult to maintain a nitrite-free RAS. Consequently, aquaculturists need to understand the tolerance of the organism they are farming to chronic exposure to low concentrations of nitrite.

Nitrite is an intermediate product formed by bacterial nitrification of ammonia. Nitrite in the water competes with chloride on the chloride-bicarbonate exchanger present in the apical membranes of chloride cells of fish gills. Nitrite also competes with chloride for transfer across erythrocyte membranes leading to the oxidation of hemoglobin to met-hemoglobin [3]. Consequently, excessive nitrite levels in culture systems can cause depressed growth [4], increased susceptibility to disease, and eventual mortality [5]. However, this competition with chloride decreases the detrimental effects of nitrite in marine waters and makes nitrite more dangerous in freshwater aquaculture.

Acute and chronic toxicities of nitrite have been extensively studied in freshwater species such as rainbow trout Oncorhynchus mykiss [6], Siberian sturgeon Acipenser baerii, Brandt [7], matrinxã Brycon cephalus [8], tambaqui Colossoma macropomum [9], Walleye Sander vitreus [10], mrigal carp Cirrhinus mrigala [11], European eel Anguilla anguilla [12], common carp Cyprinus carpio L. [13], and silver perch Bidyanus bidyanus [14]. Additionally, a few studies have evaluated responses of marine fish such as pompano Trachinotus marginatus [15], silver sea bream Sparus sarba [16,17], dark-banded rockfish, Sebastes inermis [18], Atlantic cod Gadus morhua [19], flounder Platichthys flesus [2], and cobia Rachycentron canadum [20] to ambient nitrite, but results vary greatly among species. Thus, we cannot use conclusions from previous work to estimate rabbitfish $S$. rivulatus tolerance to environmental nitrite.

Fish gills are multifunctional organs needed for respiration, osmoregulation, acid-base balance and nitrogenous excretion [21]. The large surface area and direct continuous contact with the surrounding water make the gills the first target to waterborne chemicals [22]. Pollutants enter the organism through the gills and exert their primary toxic effects on the bronchial epithelium [23]. Thus, morphological changes in fish gills are among the most commonly recognized responses to environmental stressors and are indicative of physical and chemical stress in marine as well as freshwater habitats [21,24]. Histopathological changes in gills such as epithelial lifting, hypertrophy, hyperplasia, epithelial necrosis, edema, and fusion of secondary lamellae are the major effects reported in fish exposed to various types of pollutants and toxic substances [24]. There are presently no published reports on the effects of ambient nitrite on rabbitfish gills.

Marbled rabbitfish Siganus rivulatus is a euryhaline, herbivorous marine fish widely distributed along the Eastern Mediterranean and East Indian Ocean [25]. This teleost is a valuable fishery species that is relatively easy to farm and thus considered of great potential for warm-water aquaculture diversification [26-28]. However, for the rabbitfish aquaculture industry to succeed, tolerance to metabolites that the fish will be exposed to has to be understood. The present

*Corresponding author: Patrick Saoud I, Department of Biology, American University of Beirut, Beirut, Lebanon, Tel: +961 3 385586; E-mail: is08@aub.edu.lb

Received June 02, 2014; Accepted September 06, 2014; Published September 16, 2014

Citation: Patrick Saoud I, Naamani S, Ghanawi J, Nasser N (2014) Effects of Acute and Chronic Nitrite Exposure on Rabbitfish Siganus rivulatus Growth, Hematological Parameters, and Gill Histology. J Aquac Res Development 5: 263 doi:10.4172/2155-9546.1000263

Copyright: ( 2014 Patrick Saoud I, et al. This is an open-access article distributed under the terms of the Creative Commons Attribution License, which permits unrestricted use, distribution, and reproduction in any medium, provided the original author and source are credited. 
work was performed to evaluate the tolerance of marbled rabbitfish to nitrite exposure. We determined acute nitrite tolerance of juvenile rabbitfish by establishing $96-\mathrm{h} \mathrm{LC}_{50}$ of $\mathrm{NO}_{2}-\mathrm{N}$. We then evaluated the effects of chronic exposure of $S$. rivulatus to nitrite on survival, growth performance, hematological and biochemical parameters. Finally, we determined levels of total hemoglobin and methemoglobin in the fish upon chronic nitrite exposure.

\section{Materials and Methods}

\section{Fish acquisition and experimental conditions}

Marbled rabbitfish S. rivulatus were caught in traps off the beach south of Beirut and immediately transported to the aquaculture laboratory at the American University of Beirut (AUB). The system was housed in an environmentally controlled facility. Photoperiod was maintained by a timer at 14:10 (Light: Dark) throughout the experiment. Dissolved oxygen concentrations were maintained above $5 \mathrm{mg} \mathrm{l}^{-1}$. Salinity was maintained at $35 \%$ and water temperature at $27^{\circ} \mathrm{C}$. Dissolved oxygen, salinity and temperature were measured daily using an YSI-85 salinometer. $\mathrm{pH}$ was maintained between 8.0 and 8.2 using sodium bicarbonate and measured using a handheld $\mathrm{pH}$ meter. Nitrite- $\mathrm{N}$ levels in the tanks were adjusted via additions of $\mathrm{NaNO}_{2}$ of a known volume from a $20 \mathrm{~g} \mathrm{l}^{-1} \mathrm{NO}_{2}-\mathrm{N}$ stock solution which was prepared before the experiment by dissolving $98.57 \mathrm{~g}$ of $99.9 \% \mathrm{NaNO}_{2}$ in 1 liter of de-ionized water. Nitrite concentrations were measured daily as described by Parsons et al. [29].

Fish were acclimated in $1 \mathrm{~m}^{3}$ circular quarantine tanks for two weeks and offered 35\% protein, 8\% lipid commercial diet (Rangen EXTR 350, Rangen Inc., Buhl, Idaho, USA) twice daily to apparent satiation. After two weeks of acclimatization, fish were size sorted and transferred to an indoor tank system consisting of 33 insulated $55-\mathrm{L}(30 \times 60 \times 30 \mathrm{~cm}$; $\mathrm{W} \times \mathrm{L} \times \mathrm{H}$ ) glass aquaria. All water used was stored in large closed tanks and treated prior to use. Seawater treatment included chlorination to remove any possible bacterial contamination, de-chlorination using sodium thiosulfate and addition of EDTA to remove possible heavy metal contamination

\section{Experimental design}

Three experiments were performed based on modifications of methods described by Clesceri et al. where applicable [30]. The protocols are USEPA approved and are standard methods for toxicity testing in aquatic environments. $\mathrm{LC}_{50}$ was considered to be the concentration at which at least half the fish in a treatment died within a set time frame.

\section{Experiment 1: Acute Nitrite Exposure (96 h LC L0 $_{50}$}

In the first experiment juvenile rabbitfish $(n=528$, average weight $=8.1 \mathrm{~g} \pm 0.5$; mean $\pm \mathrm{SD}$ ) were stocked at densities of 16 fish per aquarium in 33 aquaria for the $96 \mathrm{~h}$ toxicity test. Each tank was randomly assigned one of 11 treatments with three replicate tanks per treatment. Treatments were $0,40,50,60,70,80,90,100,110,120$ and $130 \mathrm{mg} \mathrm{l}^{-1}$ $\mathrm{NO}_{2}-\mathrm{N}$. The nitrite- $\mathrm{N}$ tested was chosen after a preliminary trial. Nitrite challenge was started by replacing ambient water with clean, nitrite free seawater and adding to each tank a calculated amount of stock solution $\left(20 \mathrm{~g} \mathrm{l}^{-1} \mathrm{NO}_{2}-\mathrm{N}\right)$ to obtain the desired $\mathrm{NO}_{2}-\mathrm{N}$ concentrations. Salinity, temperature and $\mathrm{pH}$ were controlled throughout the experiment.

Prior to exposure, all fish were fasted for $24 \mathrm{~h}$. During the test, fish were not fed and were counted twice daily at 08:00 and 19:00. The fish's behavior was observed and loss of equilibrium recorded when observed. Dead fish were removed and recorded at each counting event.
Nitrite-N concentrations in the tanks were measured daily. After $96 \mathrm{~h}$, fish were counted, behavior recorded and the experiment terminated.

\section{Experiment 2: Chronic nitrite exposure}

Aqueous nitrite concentrations that did not cause any fish mortality for $96 \mathrm{~h}$ were used in the second part of the project. Fish were size sorted (weight $=8.6 \pm 0.6 \mathrm{~g}$; length $=9.2 \pm 0.3 \mathrm{~cm}$ ) and stocked 16 per tank with three replicates per treatment. The initial Fulton's condition index $\mathrm{K}=100 \times$ (weight in $\mathrm{g}$ )/(total length in $\mathrm{cm})^{3}$ of the fish was 1.08. Each tank was aerated using submersible diffusers connected to a regenerative air blower. Six plastic barrels (200-liter) were filled with seawater and $\mathrm{NaNO}_{2}$ added to five of them to raise $\mathrm{NO}_{2}-\mathrm{N}$ concentrations to $10,20,30,40$, and $50 \mathrm{mg} \mathrm{l}^{-1}$. Water from each barrel was pumped into three tanks using a submersible powerhead pump connected to flow restrictors so that the volume of each tank was completely replaced each $12 \mathrm{~h}$. Fish were offered the Rangen commercial diet at $3 \%$ body weight divided into two daily feedings, mornings and evenings. All leftover feed and feces were siphoned out of each tank daily. All fish were group-weighed weekly and feed ration adjusted accordingly. Ammonia concentration in the tanks was measured twice a week and remained less than $0.01 \mathrm{mg} \mathrm{l}^{-1}$. The experiment was terminated after eight weeks, and all surviving fish were harvested, counted, group weighed and individually weighed. Blood was collected for haematological tests as described below.

\section{Experiment 3: methemoglobin determination}

The fish in experiment 2 were too small to allow extraction of sufficient blood for total haemoglobin and methemoglobin tests. Accordingly, larger fish were challenged with nitrite for 19 days in order to determine blood proportions of methemoglobin and total haemoglobin. Rabbitfish (weight=33.7 $\pm 0.5 \mathrm{~g}$; length $=14.1 \pm 0.5 \mathrm{~cm}$ ) were acclimated for 1 week to laboratory conditions in $1 \mathrm{~m}^{3}$ circular tanks. Nine fish were then transferred to each of 15 glass tanks used in previous experiment and maintained under experimental conditions for 19 days. Treatments were $0,10,20,30$ and $40 \mathrm{mg} \mathrm{l}^{-1} \mathrm{NO}_{2}-\mathrm{N}$. Water quality parameters were measured daily. Temperature was maintained at $27^{\circ} \mathrm{C}$, salinity at $35 \%$, oxygen remained above $5 \mathrm{mg} \mathrm{l}^{-1}, \mathrm{pH}$ was 8.0 \pm 0.2 , and $\mathrm{NH}_{3}-\mathrm{N}$ was below $0.02 \mathrm{mg} \mathrm{l}^{-1}$. Fish were offered the Rangen commercial feed at $3 \%$ body weight divided into two daily feedings, mornings and evenings. On the morning of the twentieth day after induction, fish were caught and placed in $100 \mathrm{mg} \mathrm{l}^{-1} \mathrm{MS}-222$ treated water to anaesthetize them and blood was extracted for haematology.

\section{Blood collection}

Fish were fasted for $24 \mathrm{~h}$ prior to blood collection. Blood was collected by cardiac puncture using heparin coated needles and $1 \mathrm{ml}$ syringes. Blood was collected from two to four fish per tank and pooled in order to secure a minimum volume of blood needed for analyses and transferred to heparin coated micro centrifuge tubes. Collected blood was held on ice until all samples were obtained. Hematological analyses were performed within $2 \mathrm{~h}$ of blood collection.

\section{Hematological and biochemical tests}

Blood samples with anticoagulant (sodium heparin) were used for hematological examination. Blood was diluted 1:200 using modified Natt Herrick's solution [31] and total blood cell numbers, Total Erythrocyte Counts (TECs) and White Blood Cells (WBCs) counted using a modified Neubauer hemocytometer. Differential blood cell counts were performed on blood films fixed with absolute methanol, and stained with modified Wright's- Giemsa stain. A total of 800 White 
Blood Cells (WBCs) per slide were identified and counted as described by Ellis [32] and Ainsworth [33]. Each type of blood cell was expressed as a percentage of the total number of blood cells examined.

Hematocrit measurements were made in duplicate by drawing well-mixed blood into heparin-coated microhematocrit tubes (75 mm length, inside diameter $1 \mathrm{~mm}, \mathrm{ABCO}$, Dealers, Inc., IL, USA) and centrifuged at $10,000 \mathrm{~g}$ for $5 \mathrm{~min}$ in a microhematocrit centrifuge. Total hemoglobin was determined by the cyanmethemoglobin technique using Drabkin's reagent (Sigma) and light absorption at $540 \mathrm{~nm}$ [34]. Total Plasma Protein (TPP) was determined by placing a drop of blood plasma onto a plasma protein veterinary refractometer (RHC-200ATC, Westover Scientific, Inc., WA, USA). Lactate was measured using a hand-held device (Accutrend Plus System, Roche Diagnostics GmbH). Plasma nitrite levels were determined according to Shechter et al. [35]. Nitrite is not stable in an acidic environment, so an alkaline extraction in six parts zinc sulphate $(4.31 \%)$ and five parts of $\mathrm{NaOH}(0.8 \%)$ was performed and the resultant solution was maintained at $0^{\circ} \mathrm{C}$ for $60 \mathrm{~min}$ then centrifuged for $15 \mathrm{~min}$ at $1000 \mathrm{rpm}$. An aliquot of the resulting supernatant was used for nitrite determination by adding sulphanilic acid and Cleve's acid. This produced a final red-violet product, and nitrite concentration was calculated from absorbance at $520 \mathrm{~nm}$.

Percentage Methemoglobin (MetHb) in the blood of fish exposed to nitrite was measured using a modification of the method described by Horecker and Brackett [36]. Briefly, $300 \mu \mathrm{l}$ of whole blood was added to $3 \mathrm{ml}$ of hemolyzing solution and vortexed to promote lysis of erythrocytes. The resulting solution was divided into two equal portions. To one portion, $20 \mu \mathrm{l}$ of $10 \%$ potassium ferricyanide $\mathrm{K}_{3} \mathrm{Fe}(\mathrm{CN})_{6}$ solution was added. All samples were then centrifuged for 3 min at $10,000 \mathrm{~g}$ and $4^{\circ} \mathrm{C}$. One milliliter of each supernatant was placed into cuvettes. Absorbance of the untreated [without $\mathrm{K}_{3} \mathrm{Fe}(\mathrm{CN})_{6}$ ] and treated [with $\mathrm{K}_{3} \mathrm{Fe}(\mathrm{CN})_{6}$ ] samples at $820 \mathrm{~nm}$ were recorded as $\mathrm{A}_{1}$ and $B_{1}$, respectively. $10 \mu \mathrm{l}$ of non-neutralized cyanide solution was added to each cuvette, and the new absorbance recorded as $A_{2}$ and $B_{2}$. The percentage MetHb was calculated as follows: $\% \mathrm{MetHb}=100\left(\mathrm{~A}_{1}-\mathrm{A}_{2}\right) /$ $\left(\mathrm{B}_{1}-\mathrm{B}_{2}\right)$.

\section{Histology of gills}

In Experiment 2, three fish from each tank were taken for histological examination. Gills were excised and samples were immediately fixed in Bouin's fixative, dehydrated using gradients of alcohol concentrations and embedded in paraffin. Sections $(5 \mu \mathrm{m})$ were stained with Ehrlich's haematoxylin and counter stained with eosin. Then the tissue specimens were dehydrated, cleared in xylene and embedded in paraffin. Slides were examined using a light microscope.

\section{Statistical analysis}

All statistical analyses were performed using SAS for Windows (V8e, SAS Institute Inc., Cary, North Carolina USA), with a significance level $\alpha=0.05$. LC $_{50}$ values with $95 \%$ confidence limits were determined using probit analysis of $\log _{10}$ transformed concentration values. Growth and hematology variables were analyzed using one way analysis of variance (ANOVA) to test for significance assuming a completely randomized experimental design. Student-Newman-Keuls mean separation tests were used to determine differences among treatment means in all experiments.

\section{Results}

\section{Acute nitrite exposure $\left(96 \mathrm{~h} \mathrm{LC}_{50}\right)$}

The $\mathrm{NO}_{2}-\mathrm{N} 96 \mathrm{~h} \mathrm{LC}_{50}$ of $S$. rivulatus juveniles was $105 \mathrm{mg} \mathrm{l}^{-1}$ with
$95 \%$ confidence limits between 97.8 and $114.3 \mathrm{mg} \mathrm{l}^{-1}$. All fish survived for $96 \mathrm{~h}$ in the treatments containing nitrite concentrations from 0 to $60 \mathrm{mg} \mathrm{l}^{-1}$. Some mortality was observed in treatments containing nitrite concentrations from 70 to $100 \mathrm{mg} \mathrm{l}^{-1}$ (Figure 1). Mortalities increased significantly at $110 \mathrm{mg} \mathrm{l}^{-1}$ where half of the fish were dead after a $96 \mathrm{~h}$ exposure. Almost all fish in treatments 120 and $130 \mathrm{mg} \mathrm{l}^{-1} \mathrm{NO}_{2}-\mathrm{N}$ were dead at $96 \mathrm{~h}$.

Mortality of rabbitfish juveniles after a 24 hour exposure was $0 \%$ for nitrite concentrations ranging from 0 to $120 \mathrm{mg} \mathrm{l}^{-1}$, and was only $2 \%$ at $130 \mathrm{mg} \mathrm{l}^{-1}$. After $48 \mathrm{~h}$ of nitrite exposure, mortality of juveniles was $0 \%$ for nitrite- $\mathrm{N}$ concentrations of 0 to $80 \mathrm{mg} \mathrm{l}^{-1}$, and increased with nitrite- $\mathrm{N}$ increase between 90 and $130 \mathrm{mg} \mathrm{l}^{-1}$. Significant differences among treatments started appearing after $48 \mathrm{~h}$ of exposure and became more apparent with time. After $96 \mathrm{~h}$ of exposure, most of the fish had died in 120 and $130 \mathrm{mg} \mathrm{l}^{-1} \mathrm{NO}_{2}-\mathrm{N}$ (Figure 1). Fish exposed to nitrite concentrations ranging from 0 to $70 \mathrm{mg} \mathrm{l}^{-1}$, exhibited no abnormal behavior. Fish swam normally with no loss of balance or orientation. However, at greater nitrite concentrations, fish exhibited erratic swimming, and were occasionally observed lying still at the bottom of the containers. At $\mathrm{NO}_{2}-\mathrm{N}$ concentrations of 110,120 and $130 \mathrm{mg} \mathrm{l}^{-1}$, all fish were lethargic and dark in color, thus exhibiting usual signs of stress in marbled rabbitfish.

\section{Chronic nitrite exposure}

Growth and survival: All fish in treatment $50 \mathrm{mg} \mathrm{l}^{-1} \mathrm{NO}_{2}-\mathrm{N}$ died by the end of the fourth week (Table 1). All fish at $0 \mathrm{mg} \mathrm{l}^{-1} \mathrm{NO}_{2}-\mathrm{N}$ survived. Mortality was observed in treatments 10 and $20 \mathrm{mg} \mathrm{l}^{-1} \mathrm{NO}_{2}-\mathrm{N}$ but results were not significantly different from the control. In treatments

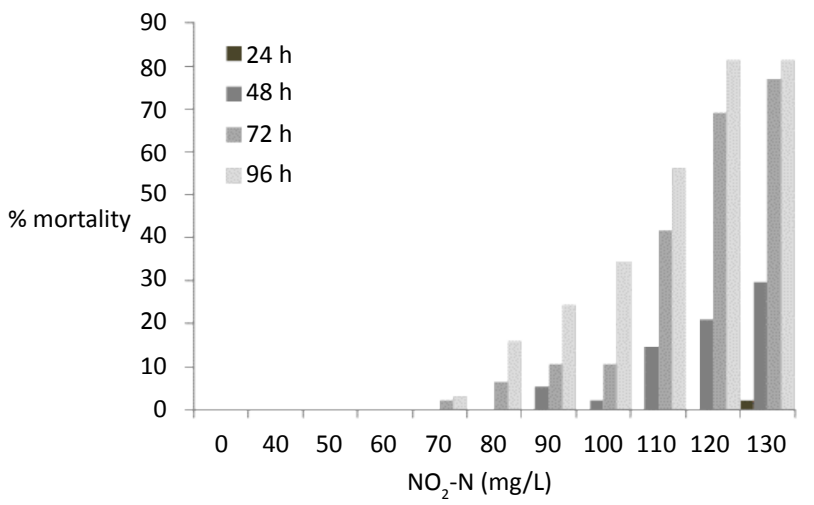

Figure 1: Rabbitfish (Siganus rivulatus) mortality during acute exposure to various $\mathrm{NO}_{2}-\mathrm{N}$ concentrations $\left(0-130 \mathrm{mg} \mathrm{l}^{-1}\right)$.

\begin{tabular}{|l|c|c|c|c|c|c|}
\hline $\mathbf{N O}_{\mathbf{2}}-\mathbf{N}\left(\mathbf{m g ~ l}^{-1}\right)$ & $\mathbf{S}(\mathbf{\%})$ & $\mathbf{W t}_{\mathbf{f}} \mathbf{( g )}$ & $\left.\mathbf{T L}_{\mathbf{f}} \mathbf{( c m}\right)$ & $\mathbf{K}_{\mathbf{f}}$ & $\mathbf{H S I}_{\mathbf{i}}$ & $\mathbf{H S I}_{\mathbf{f}}$ \\
\hline 0 & $100^{\mathrm{a}}$ & $14.8^{\mathrm{a}}$ & $11.15^{\mathrm{a}}$ & 1.06 & 1.67 & 1.66 \\
\hline 10 & $84.7^{\mathrm{a}}$ & $9.6^{\mathrm{b}}$ & $9.65^{\mathrm{b}}$ & 1.02 & 1.67 & 1.90 \\
\hline 20 & $76.5^{\mathrm{a}}$ & $7.6^{\mathrm{b}}$ & $9.09^{\mathrm{b}}$ & 1.00 & 1.67 & 1.91 \\
\hline 30 & $47.0^{\mathrm{b}}$ & $7.2^{\mathrm{b}}$ & $8.99^{\mathrm{b}}$ & 0.98 & 1.67 & 1.51 \\
\hline 40 & $40.0^{\mathrm{b}}$ & $7.1^{\mathrm{b}}$ & $8.97^{\mathrm{b}}$ & 0.96 & 1.67 & 1.22 \\
\hline PSE $^{\star}$ & 6.42 & 0.72 & 0.22 & 0.03 & - & 0.19 \\
\hline
\end{tabular}

Table 1: Survival $(S)$, final weight $\left(\mathrm{Wt}_{\mathrm{f}}\right)$, final total length $\left(\mathrm{TL}_{\mathrm{f}}\right)$, final Fulton-type condition index $\left(\mathrm{K}_{\mathrm{f}}\right)$, initial hepatosomatic $\left(\mathrm{HSI}_{\mathrm{s}}\right)$ and final hepatosomatic index ( $\mathrm{HSI}_{\mathrm{f}}$ ) of rabbitfish ( Siganus rivulatus) exposed to various nitrite- $\mathrm{N}$ concentrations $\left(0-50 \mathrm{mg} \mathrm{l}^{-1}\right)$ for 56 days.

Values in the same column sharing the same letter are not significantly different from each other.

*PSE=Pooled standard error 
Citation: Patrick Saoud I, Naamani S, Ghanawi J, Nasser N (2014) Effects of Acute and Chronic Nitrite Exposure on Rabbitfish Siganus rivulatus Growth, Hematological Parameters, and Gill Histology. J Aquac Res Development 5: 263. doi:10.4172/2155-9546.1000263

Page 4 of 9

30 and $40 \mathrm{mg} \mathrm{l}^{-1} \mathrm{NO}_{2}-\mathrm{N}$ survival were $47.0 \%$ and $40.0 \%$ respectively, significantly less than in lower concentration treatments (Table 1). The final weight and final length of fish in treatment $0 \mathrm{mg} \mathrm{l}^{-1}$ were greater than final weight and final length of fish in all other treatments. There were no significant differences in final weight and final length among treatments 10, 20, 30 and $40 \mathrm{mg} \mathrm{l}^{-1}$ although a decreasing trend in growth was observed as nitrite concentration increased (Table 1).

Although final condition index (Kf) decreased as nitrite concentration increased, results were not significantly different from each other among treatments (Table 1). There were also no significant differences in initial Hepato-Somatic Index (HSI) or in final HSI among treatments (Table 1).

Hematological and biochemical parameters: Total Erythrocyte Count (TEC) decreased progressively with increasing nitrite concentrations (Table 2). Compared to the initial value $\left(3.86 \times 10^{6} \mu \mathrm{l}\right.$ $\left.{ }^{1}\right)$, a significant reduction $(\mathrm{P}<0.05)$ in TECs was observed at all nitrite concentrations from $10 \mathrm{mg} \mathrm{l}^{-1}\left(2.86 \times 10^{6} \mathrm{\mu l}^{-1}\right)$ to $40 \mathrm{mg} \mathrm{l}^{-1}\left(1.67 \times 10^{6} \mu \mathrm{l}^{-1}\right)$ (Table 2). Hematocrit (Ht) values in treatments 20,30 , and $40 \mathrm{mg} \mathrm{l}^{-1}$ $\mathrm{NO}_{2}-\mathrm{N}$ were significantly less $(\mathrm{P}<0.05)$ than $\mathrm{Ht}$ values at 0 and $10 \mathrm{mg} \mathrm{l}^{-1}$ $\mathrm{NO}_{2}-\mathrm{N}$ (Table 2). Significantly lower total hemoglobin $(\mathrm{Hb})$ levels were found in fish exposed to 10,20,30, and $40 \mathrm{mg} \mathrm{l}^{-1} \mathrm{NO}_{2}-\mathrm{N}$ compared to the control (Table 2).

Total Leukocyte Count (TLC) of fish in treatments 10, 20 and 30 $\mathrm{mg} \mathrm{l}^{-1} \mathrm{NO}_{2}-\mathrm{N}$ were significantly greater than TLC in the control group $(\mathrm{P}<0.05)$ (Table 2). However, TLC in fish at $40 \mathrm{mg} \mathrm{l}^{-1} \mathrm{NO}_{2}-\mathrm{N}$ was significantly less than TLC in other treatments $(\mathrm{P}<0.05)$. TLC in fish at $40 \mathrm{mg} \mathrm{l}^{-1} \mathrm{NO}_{2}-\mathrm{N}$ was even less than TLC in control fish although the difference was not statistically significant (Table 2).

Average Total Plasma Protein (TPP) content in control fish was $3.92 \mathrm{~g} \mathrm{dl}^{-1}$. A reduction in TPP was observed with increasing nitrite concentrations (Table 2). At $40 \mathrm{mg} \mathrm{l}^{-1} \mathrm{NO}_{2}-\mathrm{N}$, TPP was significantly less than in fish in all other treatments. There was no significant difference in TPP among all other treatments (Table 2). Lactate levels increased as nitrite concentrations increased, but there were no significant differences among treatments (Table 2).

Neutrophil numbers increased progressively with increasing nitrite concentrations. The proportion of neutrophils in the blood of fish at 20,30, and $40 \mathrm{mg} \mathrm{l}^{-1} \mathrm{NO}_{2}-\mathrm{N}$ were significantly greater than in the control (Table 3). The proportion at $30 \mathrm{mg} \mathrm{l}^{-1} \mathrm{NO}_{2}-\mathrm{N}$ was greater than at $10 \mathrm{mg} \mathrm{l}^{-1}$ and the proportion at $40 \mathrm{mg} \mathrm{l}^{-1}$ was greater than the neutrophil proportion of the fish blood at all other treatments (Table 3 ). Eosinophil proportion in blood also increased with increasing ambient nitrite concentrations and in fish maintained at $40 \mathrm{mg} \mathrm{l}^{-1} \mathrm{NO}_{2}-\mathrm{N}$ it was

\begin{tabular}{|c|c|c|c|c|c|c|}
\hline $\begin{array}{l}\mathrm{NO}_{2}-\mathrm{N} \\
\left(\mathrm{mg} \mathrm{l}^{-1}\right)\end{array}$ & $\begin{array}{c}\mathrm{Ht} \\
(\%)\end{array}$ & $\begin{array}{l}\text { Total Hb } \\
\left(\mathrm{mg} \mathrm{dl}^{-1}\right)\end{array}$ & $\begin{array}{c}\text { TEC } \\
\left(\times 10^{6} \mu^{-1}\right)\end{array}$ & $\begin{array}{c}\text { TLC } \\
\left(\times 10^{6} \mathrm{~mm}^{-3}\right)\end{array}$ & $\begin{array}{c}\mathrm{TPP} \\
\left(\mathrm{g} \mathrm{dl}^{-1}\right)\end{array}$ & $\begin{array}{c}\text { Lactate } \\
\left(\mathrm{mmol} \mathrm{I}^{-1}\right)\end{array}$ \\
\hline 0 & $36.65^{a}$ & $11.67^{\mathrm{a}}$ & $3.86^{a}$ & $77.81^{b}$ & $3.92^{\mathrm{a}}$ & 2.33 \\
\hline 10 & $32.38^{a}$ & $8.68^{b}$ & $2.86^{b}$ & $108.19^{a}$ & $3.86^{a}$ & 2.72 \\
\hline 20 & $22.33^{b}$ & $6.06^{b}$ & $2.33^{b c}$ & $121.67^{a}$ & $3.17^{a}$ & 2.03 \\
\hline 30 & $22.63^{b}$ & $5.77^{\mathrm{b}}$ & $2.31^{b, c}$ & $108.88^{a}$ & $3.18^{a}$ & 2.23 \\
\hline 40 & $20.50^{b}$ & $5.32^{b}$ & $1.67^{c}$ & $65.13^{b}$ & $2.10^{\mathrm{b}}$ & 3.30 \\
\hline PSE* & 2.31 & 0.47 & 0.28 & 8.21 & 0.28 & 0.59 \\
\hline
\end{tabular}

Table 2: Hematological and Biochemical parameters of rabbitfish Siganus rivulatus exposed to various nitrite- $\mathrm{N}$ concentrations $\left(0-50 \mathrm{mg} \mathrm{l}^{-1}\right)$ for 56 days.

Values in the same column sharing the same letter are not significantly different from each other.

$\mathrm{Ht}=$ Hematicrit; $\mathrm{Hb}=$ hemoglobin; $\mathrm{TEC}=$ Total erythrocyte count; $\mathrm{TLC}=$ Total leukocyte count; TPP=total plasma protein.

${ }^{*} \mathrm{PSE}=$ Pooled standard error

\begin{tabular}{|l|c|c|c|c|c|}
\hline $\begin{array}{l}\mathbf{N O}_{2}-\mathbf{N} \\
\mathbf{~ m g ~ l}^{-1} \mathbf{1}\end{array}$ & $\begin{array}{c}\text { Thrombocytes } \\
\mathbf{( \% )}\end{array}$ & $\begin{array}{c}\text { Neutrophils } \\
\mathbf{( \% )}\end{array}$ & $\begin{array}{c}\text { Lymphocytes } \\
\mathbf{( \% )}\end{array}$ & $\begin{array}{c}\text { Monocytes } \\
\mathbf{( \% )}\end{array}$ & $\begin{array}{c}\text { Eosinophils } \\
(\mathbf{\%})\end{array}$ \\
\hline 0 & $80.00^{\mathrm{a}}$ & $8.78^{\mathrm{d}}$ & $10.89^{\mathrm{b}}$ & 0.56 & $0.11^{\mathrm{b}}$ \\
\hline 10 & $68.11^{\mathrm{a}, \mathrm{b}}$ & $17.22^{\mathrm{c}, \mathrm{d}}$ & $13.89^{\mathrm{b}}$ & 0.56 & $0.22^{\mathrm{b}}$ \\
\hline 20 & $53.14^{\mathrm{b}}$ & $28.43^{\mathrm{b}, \mathrm{c}}$ & $16.43^{\mathrm{b}}$ & 1.14 & $0.71^{\mathrm{b}}$ \\
\hline 30 & $35.25^{\mathrm{c}}$ & $34.00^{\mathrm{b}}$ & $29.25^{\mathrm{a}}$ & 1.25 & $1.25^{\mathrm{b}}$ \\
\hline 40 & $11.00^{\mathrm{d}}$ & $54.00^{\mathrm{a}}$ & $30.50^{\mathrm{a}}$ & 2.00 & $2.75^{\mathrm{a}}$ \\
\hline PSE $^{*}$ & 5.25 & 4.20 & 2.40 & 0.42 & 0.31 \\
\hline
\end{tabular}

Table 3: Average percentages of differential blood counts in Siganus rivulatus rabbitfish after exposure to 56 days chronic nitrite experiment.

Values in the same column sharing the same letter are not significantly different from each other.

*PSE=Pooled standard error

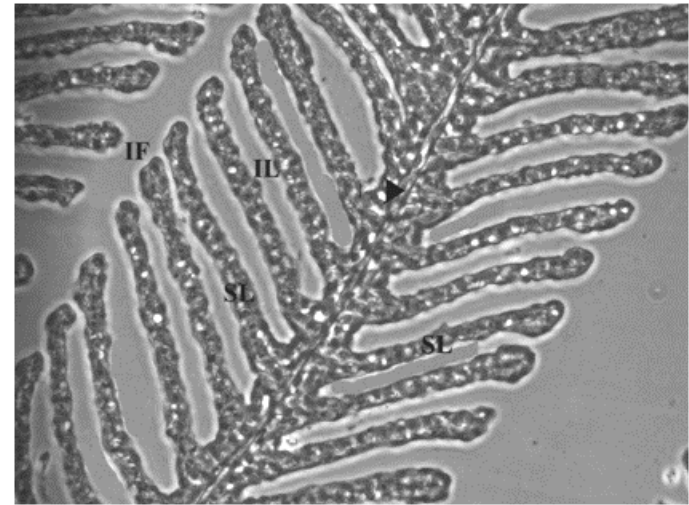

Figure 2: Light micrographs of gills of fish reared in nitrite free water. Gills have normal architecture, good integrity of the central axis $(\downarrow)$, parallel and well organized secondary lamellae (SL) and evident interfilament (IF) space and interlamellar (IL) space. [Formalin fixed-H\&E stained preparation, X 400].

significantly different from all other treatments (Table 3). Lymphocytes proportion in blood of control fish was $10.89 \%$, increasing to $13.89 \%$ and $16.43 \%$ in blood of fish at 10 and $20 \mathrm{mg} \mathrm{l}^{-1} \mathrm{NO}_{2}-\mathrm{N}$ respectively (Table 3). However, the differences were not significantly different from each other. In blood of fish maintained at 30 and $40 \mathrm{mg} \mathrm{l}^{-1} \mathrm{NO}_{2}-\mathrm{N}$, lymphocyte proportions increased significantly to reach 29.25 and $30.50 \%$ of WBCs, respectively (Table 3 ). Thrombocytes proportion in blood of control fish was $80.0 \%$ and decreased significantly as ambient nitrite increased. In blood of fish maintained at $40 \mathrm{mg} \mathrm{l}^{-1}$ $\mathrm{NO}_{2}-\mathrm{N}$, thrombocytes comprised only $11 \%$ of total WBCs (Table 3). Monocytes proportion in blood increased with an increase in ambient nitrite concentrations but values were not significantly different among treatments (Table 3). No basophils were found in any of the hematological slides that were examined.

Histology: Gill preparations of control fish had normal gill architecture and typical structural organization of gill filaments (Figure 2). The structure of the lamellae observed was comparable to gills described by Gisbert et al. [7] and Kroupova et al. [6] for healthy fish. The gill arch was composed of healthy looking long gill filaments (primary lamellae) bearing distinct secondary lamellae on both sides and well separated with evident interlamellar space. Secondary lamellae were evenly arranged, running parallel to each other, and also showed clear interlamellar spaces.

Gill preparations of fish in $10 \mathrm{mgl}^{-1} \mathrm{NO}_{2}-\mathrm{N}$ revealed distinguishable deformations and apparent gill damage such as twisted uneven 
Citation: Patrick Saoud I, Naamani S, Ghanawi J, Nasser N (2014) Effects of Acute and Chronic Nitrite Exposure on Rabbitfish Siganus rivulatus Growth, Hematological Parameters, and Gill Histology. J Aquac Res Development 5: 263. doi:10.4172/2155-9546.1000263

secondary lamellae, fusion and hyperplasia of secondary lamellae. Fish exposed to $20 \mathrm{mg} \mathrm{l}^{-1}$ nitrite nitrogen had dilations of central axes and infiltration of red blood cells with hyperplasia of spiked and shortened secondary lamellae. Fish exposed to $30 \mathrm{mg} \mathrm{l}^{-1}$ nitrite nitrogen hadblunt ended secondary lamellae with aneurysms, and hypertrophy and hyperplasia of epithelial cells (Figure 3). Gills of fish exposed to $40 \mathrm{mg} \mathrm{l}^{-1} \mathrm{NO}_{2}-\mathrm{N}$ revealed significant disorganization and twisting of secondary lamellae with severe hyperplasia leading to lamellar fusion. Additionally, aneurysms and vascular congestions of lamellae were observed. Fish exposed to $50 \mathrm{mgl}^{-1} \mathrm{NO}_{2}-\mathrm{N}$ exhibited complete loss of gill structure resulting from lysis at several points (Figure $4 \mathrm{a}$ and $4 \mathrm{~b}$ ). Gill alteration included irregular, twisted and curled secondary lamellae, and severe gill hypertrophy, hyperplasia, lamellar telangiectasia and ruptures of lamellar epithelia, and lamellar fusion.

Plasma nitrite and methemoglobin determination: Blood hemoglobin (total $\mathrm{Hb}$ ) of the rabbitfish decreased as ambient nitrite increased. Significantly lesser total hemoglobin levels were found in fish exposed to 10, 20, 30, and $40 \mathrm{mg} \mathrm{l}^{-1} \mathrm{NO}_{2}-\mathrm{N}$ compared to the control (Figure 5a). Moreover, the percentage of MetHb increased significantly in fish exposed to 30 and $40 \mathrm{mg} \mathrm{l}^{-1} \mathrm{NO}_{2}-\mathrm{N}$ concentrations compared with controls, and reached proportions between 28.55 and $71.40 \%$ of the total $\mathrm{Hb}$ respectively (Figure $5 \mathrm{~b}$ ). Plasma nitrite concentration increased significantly with increasing aqueous nitrite concentrations (Figure 5c). At $0 \mathrm{mg} \mathrm{l}^{-1}$ ambient $\mathrm{NO}_{2}-\mathrm{N}$, plasma nitrite was $0.05 \mathrm{mg} \mathrm{l}^{-1}$ and increased nearly ten-fold to $0.47 \mathrm{mg} \mathrm{l}^{-1}$ when fish were maintained at $40 \mathrm{mg} \mathrm{l}^{-1} \mathrm{NO}_{2}-\mathrm{N}$ for 19 days.

\section{Discussion}

\section{Acute nitrite exposure $\left(96 \mathrm{~h} \mathrm{LC}_{50}\right)$}

Results of the acute nitrite toxicity study indicated that $S$. rivulatus juveniles have a $96 \mathrm{~h} \mathrm{LC}_{50}$ of $10^{5} \mathrm{mg} \mathrm{l}^{-1} \mathrm{NO}_{2}-\mathrm{N}$. Fish challenged with excessive nitrite exhibited erratic swimming, disorientation and lack of balance within $48 \mathrm{~h}$ of exposure. Similar behavior was reported in cobia exposed to nitrite by Rodrigues et al. [20]. The impaired swimming performance is possibly because of increased MetHb in the blood that causes a decrease in $\mathrm{O}_{2}$ available to tissues thus limiting activity [37]. Margiocco et al. found that nitrite concentrations in liver, brain, gills and muscles do not reach the same levels as in the blood, which suggests that blood is the primary target of nitrite toxicity and that in turn affects all the other organs by reducing oxygen delivery [38].

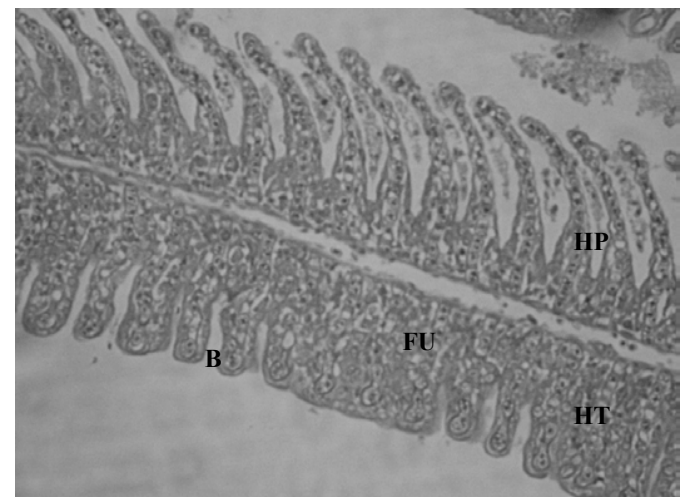

Figure 3: Light micrographs of gills of fish reared in $30 \mathrm{ppm}$ nitrite-N. Gill damage is apparent. Notice lamellar fusion (FU) and hypertrophy (HT), and hyperplasia (HP) of the twisted irregular secondary lamellae with blunt ends (B). [Formalin fixed-H\&E stained preparation, $X$ 200].

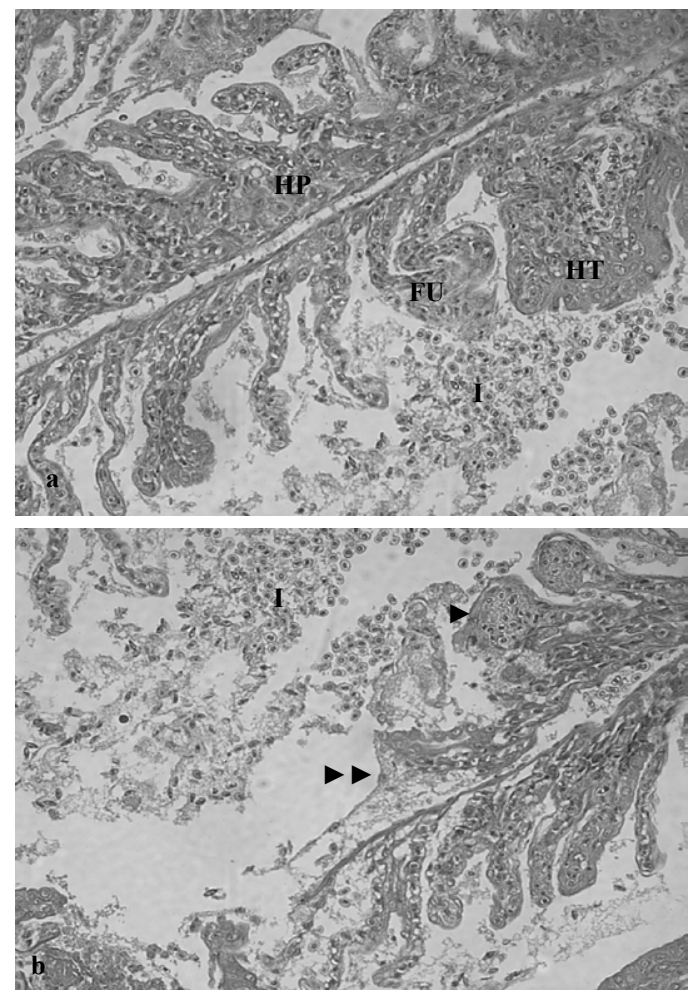

Figure 4: $\mathbf{a}$ and $\mathbf{b}$ : Light micrographs. Gills of group 6 (50 ppm nitrite). a) Showing marked histological alterations and severe deformations with severe irregular and curled secondary lamellae, extensive hypertrophy (HT) leading to severe lamellar fusion (FU) of secondary lamellae with severe blood infiltration (I). b) Revealing remarkable and widespread tissue damage and lysis at several points $(\longrightarrow)$ with severe telangiectasia $(\rightarrow)$ and infiltration of blood cells (I). [Formalin fixed- H\&E stained preparation, $X$ 400].

No data about the tolerance of marbled rabbitfish to nitrite is reported in the literature. However, when compared to various other marine species, S. rivulatus shows middle-of-range tolerance to nitritenitrogen. The flounder Paralichthys orbignyanus is the most sensitive marine fish on record with a $96 \mathrm{~h} \mathrm{LC}_{50}$ of $30 \mathrm{mg} \mathrm{l}^{-1} \mathrm{NO}_{2}-\mathrm{N} \mathrm{[39]} \mathrm{and}$ the dark-banded rockfish Sebastes inermis is the least sensitive fish reported, with a $96 \mathrm{~h} \mathrm{LC}_{50}$ of $700 \mathrm{mg} \mathrm{l}^{-1} \mathrm{NO}_{2}-\mathrm{N}$ [18]. Other species show intermediary toxicity: $85 \mathrm{mg} \mathrm{l}^{-1} \mathrm{NO}_{2}-\mathrm{N}$ for red drum Sciaenops ocellatus [40] and $199 \mathrm{mg} \mathrm{l}^{-1} \mathrm{NO}_{2}-\mathrm{N}$ for the marine pejerrey Odontesthes argentinensis [41]. Tolerance of $S$. rivulatus to short-term nitrite exposure is closest to that of Siberian sturgeon Acipenser baeri having $\mathrm{LC}_{50}$ of $130 \mathrm{mg} \mathrm{l}^{-1} \mathrm{NO}_{2}-\mathrm{N}$ [16]. Although nitrite tolerance changes with age, our interest was in tolerance of juveniles because these are the age groups important to aquaculturists.

\section{Chronic nitrite exposure}

Survival and growth of juvenile marbled rabbitfish exposed to $\mathrm{NO}_{2}-\mathrm{N}$ concentrations of 10 to $40 \mathrm{mg} \mathrm{l}^{-1}$ over 56 days decreased as the nitrite concentration increased. However, nitrite uptake, toxicity, and effects vary among fish species and life stages $[3,42,43]$, as well as with environmental conditions such as temperature [44], thus making comparison of toxicity values among studies difficult.

Although studies on long-term effects of aqueous nitrite on growth and survival of marine fish are relatively scarce, there are reports that increasing nitrite levels lead to net reductions in growth and/or survival of various fish species $[4,6,14]$. Our results indicate growth 


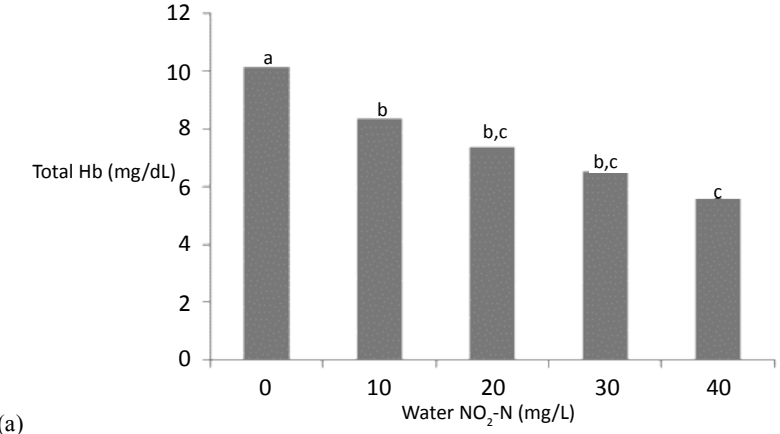

(a)

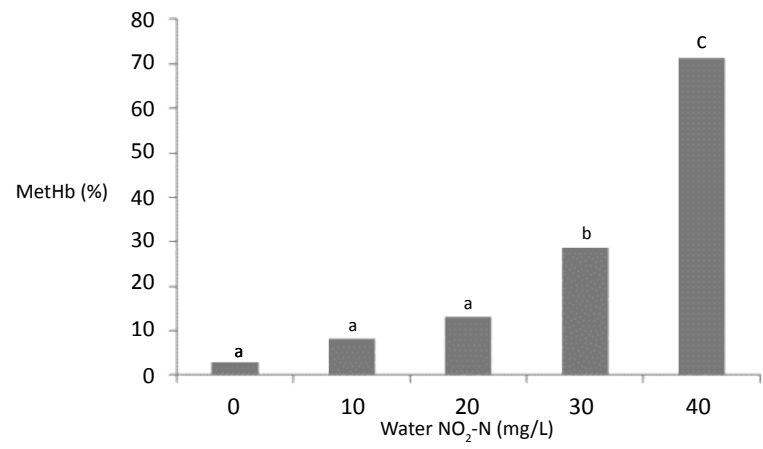

(b)

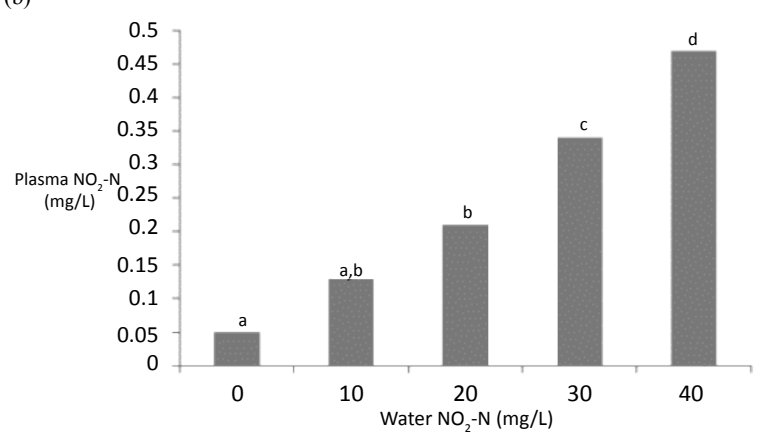

(c)

Figure 5: $(\mathbf{a}, \mathbf{b}, \mathbf{c})$ : Plasma nitrite $\left(\mathrm{NO}_{2}-\mathrm{N}\right)$, total hemoglobin (total $\left.\mathrm{Hb}\right)$ and methemoglobin values $(\mathrm{MetH})$ of rabbitfish Siganus rivulatus exposed to various nitrogen nitrite concentrations $\left(0-40 \mathrm{mg} \mathrm{l}^{-1}\right)$ for 19 days.

suppression and mortality but these results were only significant at the greater nitrite concentrations (30 and $40 \mathrm{mg} \mathrm{l}^{-1} \mathrm{NO}_{2}-\mathrm{N}$ ) used in the present experiment. A similar trend of reduction in growth of marine fish concomitant with increasing nitrite concentrations was reported by Siikavuopio and Saether working with juvenile cod Gadus morhua [19]. However, growth suppression was not always correlated with increasing nitrite concentrations. Wedemeyer and Yasutake found no growth suppression of steelhead trout Salmo gairdneri exposed to low nitrite concentrations for six months [45]. Similarly, Kamstra et al., observed no growth reduction in European eel Anguilla anguilla exposed to sub-lethal nitrite concentrations [46].

Finally, no significant differences in HSI among fish exposed to the various nitrite concentrations were observed in the present work. Similar results were observed by Deane and Woo working with the bream Sparus sarba [17]. Apparently, although nitrite is partly detoxified by the liver of some fishes such as rainbow trout [47], most of the mitigation is performed by methemoglobin reductase in oxygenated RBCs $[3,48]$, thus possibly sparing the liver. However, nitrite has been reported to cause some liver damage in various fishes [49-51]. Huang and Chen suspected liver necrosis in eel Anguilla anguilla following exposure to very low levels of nitrite [12]. Nitrite does not seem to have similar deleterious effects on rabbitfish livers as it has on livers of some other fishes.

A significant reduction in total erythrocyte count as observed in the present work was reported in various freshwater fishes $[9,11]$ and Park et al. [18] reported a decrease in hemoglobin content with increasing nitrite concentrations in the marine dark-banded rockfish. Jensen suggested that significant changes in the blood parameters of fish caused by nitrite exposure, such as reduction in total erythrocyte count, total $\mathrm{Hb}$ concentration, and $\mathrm{Ht}$ levels, may be a consequence of passage of nitrite into the blood stream causing RBC hemolysis [52]. The problems are further compounded because hemolysis results in efflux of RBC potassium, leading to RBC shrinkage and creating a situation of oxygen shortage in the fish [52-54].

Leukocytes are involved in the regulation of immunological functions and their numbers increase as fish respond to stressful conditions [55-57]. Although some authors consider fish thrombocytes to be equivalent to platelets in mammals, we consider thrombocytes as complete white blood cells as suggested by Tavares-Dias and Oliveira [58]. In the present study, TLC increased with increase in nitrite concentration up to $20 \mathrm{mg} \mathrm{l}^{-1} \mathrm{NO}_{2}-\mathrm{N}$ then decreased at greater nitrite-N concentrations ( 30 and $40 \mathrm{mg} \mathrm{l}^{-1}$ ). Similar results were found in Cirrhinus mrigala (Ham) where TLC increased with increasing nitrite concentrations and then decreased with further exposure [11]. Possibly, the excessive stress caused failure/exhaustion of leukopoiesis, resulting in reduction of TLC at higher nitrite concentrations [11]. It is also possible that decreased oxygen content of the blood affected hemopoietic tissues such as the kidney.

Differential leukocyte counts of juvenile Siganus rivulatus in the present study showed an increase in the percentages of neutrophils, lymphocytes, monocytes, and eosinophils concomitant with an increase in nitrite concentrations. Such results are not surprising considering stress generally causes neutrophilia in fish [59]. Moreover, Das et al. reported that lymphocyte and monocyte prevalence is affected by hypoxic stress [11]. No basophils were observed in blood of fish in the present experiment. Apparently, such results are common in Mediterranean and Red Sea fishes. No basophils were found in blood of six Mediterranean fish species examined by Pavlidis et al. [60] or in 50 species of fishes from the Red Sea [61].

Total plasma protein values of Siganus rivulatus showed a decreasing trend with increasing nitrite concentrations, with a significant reduction of TPP in fish maintained at $40 \mathrm{mg} \mathrm{l}^{-1} \mathrm{NO}_{2}-\mathrm{N}$. Such results corroborate results observed in dark-banded rockfish Sebastes inermis, which when subjected to nitrite concentrations between 200$700 \mathrm{mg} \mathrm{l}^{-1} \mathrm{NO}_{2}-\mathrm{N}$ for $96 \mathrm{~h}$ portrayed a significant reduction in serum protein [18]. Similarly, Das et al. reported significant decrease of serum protein level in C. mrigala following exposure to $4-10.4 \mathrm{mg} \mathrm{l}^{-1}$ nitrite [11]. Possibly, fish require extra energy to maintain metabolism when subjected to toxicant induced stress and requirement is met by increasing protein catabolism, thereby reducing plasma protein [11]. In addition, hemolysis and removal of RBCs could cause a dilution of plasma which is also observed as a small reduction in plasma protein levels [11]. The reduction in plasma protein in the present study, 
Citation: Patrick Saoud I, Naamani S, Ghanawi J, Nasser N (2014) Effects of Acute and Chronic Nitrite Exposure on Rabbitfish Siganus rivulatus Growth, Hematological Parameters, and Gill Histology. J Aquac Res Development 5: 263. doi:10.4172/2155-9546.1000263

Page 7 of 9

concomitant with increasing nitrite concentrations is probably a result of both protein catabolism and plasma dilution.

One effect of hypoxia on fish is an increase in lactate production $[62,63]$. Woo and Chiu reported a significant increase in blood lactate of $L$. calcarifer exposed to various aqueous nitrite levels [64]. Although in the present work no significant differences were observed among blood lactate levels of fish maintained at various nitrite levels, results do suggest an increase in blood lactate of fish reared in the $40 \mathrm{mg} \mathrm{l}^{-1} \mathrm{NO}_{2}-\mathrm{N}$ waters compared to fish in other treatments. The fact that lactate increase was only observed at high nitrite levels suggests that there might be a threshold for oxygen content in the blood, below which lactate starts increasing. Similar observations of plasma lactate being only discernible in fish exposed to extremely high nitrite concentration were reported by Jensen et al. working with carp [62].

Histological changes in fish gills are among the most commonly recognized responses to environmental pollutants $[21,24,65]$. In the present study, light micrographs of gills revealed that chronic exposure to nitrite resulted in distinguishable tissue deformations and apparent gill damage as compared to gills of fish not exposed to nitrite. These observations were similar to those of Bullock [66], Larmoyeaux and Piper [67], Takashima and Hibiya [68], and Fernandes et al. [23] to name but a few.

In several slides, epithelial lifting and lysis of some blood sinuses were observed. Epithelial lifting possibly served as a defense mechanism, because separation of lamellar epithelia increase the distance across which waterborne pollutants must diffuse to reach the bloodstream $[69,70]$. However, as Peters et al. suggested, epithelial lifting causes an increased diffusion distance across the membrane reducing the gill's functional surface area and capacity for efficient gas exchange [71].

The most characteristic features observed in nitrite exposed fish were lamellar aneurysms. The lamellar aneurysms are believed to result from the collapse of pillar cell systems and the breakdown of vascular integrity with a release of large quantities of blood that push the lamellar epithelium outward [72]. In the present study, excessive nitrite caused severe histopathological alterations in the gills of Siganus rivulatus and may be the reason for the mortality observed. Fish exposed to lesser nitrite concentrations exhibited histological signs of stress but were able to survive.

\section{Plasma nitrite and methemoglobin determination}

Methemoglobin levels in siganid blood increased as environmental nitrite concentration increased. At an aqueous concentration of 40 $\mathrm{mg} \mathrm{l}^{-1} \mathrm{NO}_{2}-\mathrm{N}$, blood methemoglobin reached an average of $71.4 \%$ of total hemoglobin. Similar observations are reported for sea bass Dicentrarchus labrax by Scarano et al. [50]. As the proportion of methemoglobin in the blood increased, the proportion of functional hemoglobin decreased but also the total amount of hemoglobin in the blood decreased. Such results are corroborated by Brown and Mcleay [73] and Margiocco et al. [38] suggesting that although anoxia resulting from methemoglobinemia is the primary mechanism of nitrite toxicity [74], nitrite also causes a decrease in total hemoglobin in the blood which compounds the problem. However, this observation has not been reported in all fish species exposed to nitrite. Hemoglobin decrease was not observed in sea bass exposed $24 \mathrm{~h}$ to nitrite, and was not reported in channel catfish exposed $24 \mathrm{~h}$ to $5 \mathrm{mg} \mathrm{l}^{-1} \mathrm{NO}_{2}-\mathrm{N}$ [75]. Moreover, methemoglobinemia has been questioned as the sole mechanism of nitrite toxicity in fish $[76,77]$. Regardless of the mode of action of environmental nitrite, the marbled rabbitfish is quite tolerant of nitrite if reared at a salinity of $35 \%$ making the species quite suitable for intensive aquaculture in recirculation systems.

\section{Acknowledgment}

The present work was funded by a grant from the Lebanese National Council for Scientific Research.

\section{References}

1. Tomasso JR (1994) Toxicity of nitrogenous wastes to aquaculture animals Reviews in Fisheries Science 2: 291-314.

2. Grosell M, Jensen FB (2000) Uptake and effects of nitrite in the marine teleost fish Platichthys flesus. Aquat Toxicol 50: 97-107.

3. Jensen FB (2003) Nitrite disrupts multiple physiological functions in aquatic animals. Comp Biochem Physiol 135: 9-24.

4. Colt J, Ludwig R, Tchobanoglous G, Cesh Jr JJ (1981) The effects of nitrite on the short-term growth and survival of channel catfish, Ictalurus punctatus. Aquaculture 24: 111-122

5. Svobodova Z, Machova1 J, Poleszczuk G, Huda J, Hamaakova J, et al. (2005) Nitrite poisoning of fish in aquaculture facilities with water-recirculating systems. Acta Vet Brno 74: 129-137.

6. Kroupova H, Machova J, Piackova V, Blahova J, Dobsikova R, et al. (2008) Effects of subchronic nitrite exposure on rainbow trout (Oncorhynchus mykiss). Ecotoxicol Environl Saf 71: 813-820

7. Gisbert E, Rodriguez A, Cardona L, Huertas M, Gallardo MA, et al. (2004) Recovery of Siberian sturgeon yearlings after an acute exposure to environmental nitrite: changes in the plasmatic ionic balance, $\mathrm{Na}^{+}-\mathrm{K}^{+}$ATPase activity, and gill histology. Aquaculture 239: 141-154

8. Avilez IM, Altran AE, Aguiar LH, Moraes G (2004) Hematological responses of the neotropical teleost matrinxa (Brycon cephalus) to environmental nitrite. Comp Biochem Physiol 139: 135-139.

9. Da Costa OTF, Ferreira DJDS, Mendonca FLP, Fernandes MN (2004) Susceptibility of the Amazonian fish, Colossoma macropomum (Serrasalminae) to short-term exposure to nitrite. Aquaculture 232: 627-636.

10. Madison BN, Wang YS (2006) Haematological responses of acute nitrite exposure in walleye (Sander vitreus). Aquat Toxicol 79: 16-23.

11. Das PC, Ayyappan S, Jena JK, Das BK (2004) Nitrite toxicity in Cirrhinus mrigala (Ham): acute toxicity and sub-lethal effect on selected haematological parameters. Aquaculture 235: 633-644.

12. Huang CY, Chen JC (2002) Effects on acid-base balance, methaemoglobinemia and nitrogen excretion of European eel after exposure to elevated ambient nitrite. Journal of Fish Biology 61: 712-725.

13. Svobodova Z, Machova J, Drastichova J, Groch L, Luskova V, et al. (2005) Haematological and biochemical profile of carp blood following nitrite exposure at different concentration of chloride. Aquaculture Research 36: 1177-1184.

14. Frances J, Allan GL, Nowak BF (1998) The effects of nitrite on the short-term growth of silver perch (Bidyanus bidyanus). Aquaculture 163: 63-72.

15. Costa LDF, Filho KCM, Severo MP, Sampaio LA (2008) Tolerance of juvenile pompano Trachinotus marginatus to acute ammonia and nitrite exposure at different salinity levels. Aquaculture 285: 270-272.

16. Huertas M, Gisbert E, Rodriguez A, Cardona L, Williot P, et al. (2002) Acute exposure of Siberian sturgeon (Acipenser baeri, Brandt) yearlings to nitrite: median-lethal concentration $\left(\mathrm{LC}_{50}\right)$ determination, haematological changes and nitrite accumulation in selected tissues. Aquatic Toxicology 57: 257-266.

17. Deane EE, Woo NYS (2007) Impact of nitrite exposure on endocrine osmoregulatory and cytoprotective functions in the marine teleost Sparus sarba. Aquat Toxicol 82: 85-93.

18. Park I-S, Lee J, Hur J-W, Song Y-C, Na HC, et al. (2007) Acute toxicity and sublethal effects of nitrite on selected hematological parameters and tissues in dark-banded rockfish, Sebastes inermis. Journal of the World Aquaculture Society 38: 188-199.

19. Siikavuopio SI, Saether BS (2006) Effects of chronic nitrite exposure on growth in juvenile Atlantic cod, Gadus morhua. Aquaculture 255: 351-356.

20. Rodrigues RV, Schwarz MH, Delbos BC, Sampaio LA (2007) Acute toxicity 
Citation: Patrick Saoud I, Naamani S, Ghanawi J, Nasser N (2014) Effects of Acute and Chronic Nitrite Exposure on Rabbitfish Siganus rivulatus Growth, Hematological Parameters, and Gill Histology. J Aquac Res Development 5: 263. doi:10.4172/2155-9546.1000263

and sublethal effects of ammonia and nitrite for juvenile cobia Rachycentron canadum. Aquaculture 271: 553-557.

21. Au DWT (2004) The application of histo-cytopathological biomarkers in marine pollution monitoring: a review. Mar Pollut Bulletin 48: 817-834.

22. Perry SF, Laurent $P$ (1993) Environmental effects on fish gill structure and function: recent advances and future directions. In: Jensen $\mathrm{F}$, Rankin $\mathrm{C}$ edn. Fish Ecophysiology. Chapman and Hall, London 231-264.

23. Fernandes C, Fontainhas-Fernandes A, Monteiro SM, Salgado MA (2007) Histopathological gill changes in wild leaping grey mullet (Liza saliens) from the Esmoriz-Paramos coastal lagoon, Portugal. Environ Toxicol 22: 443-448.

24. Mallat J (1985) Fish gill structural changes induced by toxicants and other irritants: a statistical review. Canadian Journal of Fisheries and Aquatic Sciences 42: 630-648.

25. Woodland DJ (1983) Zoogeography of the Siganidae (Pisces): an interpretation of distribution and richness patterns. Bulletin of Marine Science 33: 713-717.

26. Saoud IP, Kreydiyyeh S, Chalfoun A, Fakih M (2007) Influence of salinity on survival, growth, plasma osmolality and gill $\mathrm{Na}^{+}-\mathrm{K}^{+}-\mathrm{ATPase}$ activity in the rabbitfish Siganus rivulatus. Journal of Experimental Marine Biology and Ecology 384: 183-190.

27. Saoud IP, Ghanawi J, Lebbos N (2008) Effects of stocking density on survival, growth, size variation and condition index of the rabbitfish Siganus rivulatus. Aquaculture International 16: 109-116.

28. Saoud IP, Mohanna C, Ghanawi J (2008) Effects of temperature on survival and growth of juvenile rabbitfish (Siganus rivulatus). Aquaculture Research 39: 491-497.

29. Parsons TR, Maita Y, Lalli, CM (1985) A Manual of Chemical and Biological Methods for Seawater Analysis. Pergamon Press, Elmsford, New York, USA.

30. Clesceri LS, Greenberg AE, Trussell RR (1989) Standard methods for the examination of water and wastewater, 7 th edn. American Public Health Association, Washington, USA.

31. Natt MP, Herrick CA (1952) A new blood diluent for counting erythrocytes and leukocytes of the chicken. Poultry Science 31: 735-738.

32. Ellis AE (1977) The leucocytes of fish: A review. Journal of Fish Biology 11: 453-491.

33. Ainsworth AJ (1992) Fish granulocytes: morphology, distribution and function. Annual Review Fish Disease 2: 123-148.

34. Drabkin DL, Austin JH (1932) Spectrophotometric constants for common hemoglobin derivatives in human, dog, and rabbit blood. Journal of Biological Chemistry 98: 719-733.

35. Shechter H, Gruener N, Shubal HI (1972) Micromethod for the determination of nitrite in blood. Analytica Chimica Acta 60: 93-99.

36. Horecker BL, Brackett FS (1944) A rapid spectrophotometric method for the determination of methemoglobin and carbonylhemoglobin in blood. Journal of Biological Chemistry 152: 669-677.

37. Brauner CJ, Val AL, Randall DJ (1993) The effect of graded methaemoglobin levels on the swimming performance of Chinook salmon (Oncorhynchus tshawytscha). J Exp Biol 185: 121-135.

38. Margiocco C, Arill A, Mensi P, Schenone G (1983) Nitrite bioaccumulation in Salmo gairdneri Rich and hematological consequences. Aquatic Toxicology 3 : 261-270.

39. Bianchini A, Wasielesky Jr W, Miranda KC (1996) Toxicity of nitrogenous compounds to juveniles of flatfish Paralichthys orbignyanus. Bulletin of Environmental Contamination and Toxicology 56: 453-459.

40. Wise DJ, Tomasso JR (1989) Acute toxicity of nitrite to red drum Sciaenops ocelattus: effect of salinity. Journal of World Mariculture Society 20: 193-198.

41. Sampaio LA, Pisseti TL, Morena M (2006) Acute toxicity of nitrite on larvae of the marine pejerrey Odontesthes argentinensis (Teleostei, Atherinopsidae). Ciência Rural 36: 1008-1010.

42. Lewis Jr WM, Morris DP (1986) Toxicity of nitrite to fish: A review. Transactions of the American Fisheries Society 115: 183-195.

43. Martinez CBR, Souza MM (2002) Acute effects of nitrite on ion regulation in two neotropical fish species. Comp Biochem Physiol 113: 151-160.
44. Saroglia MG, Scarano G, Tibaldi E (1981) Acute toxicity of nitrite to sea bass (Dicentrarchus labrax) and European eel (Anguilla anguilla). Journal of the World Mariculture Society 12: 121-126.

45. Wedemeyer GA Yasutake WT (1978) Prevention and treatment of nitrite toxicity in juvenile steelhead trout (Salmo gairdneri). Journal of the Fisheries Research Board of Canada 35: 822-827.

46. Kamstra A, Span JA, Van Weerd JH (1996) The acute toxicity and sublethal effects of nitrite on growth and feed utilization of European eel, Anguilla anguilla (L). Aquaculture Research 27: 903-911.

47. Doblander C, Lackner R (1996) Metabolism and detoxification of nitrite by hepatocytes. Biochimica Biophys Acta 1298: 270-274.

48. Freeman L, Beitinger TL, Huey DW (1983) Methemoglobin reductase activity in phylogenetically diverse piscine species. Comparative Biochemistry and Physiology 75: 27-30.

49. Arillo A, Gaino E, Margiocco C, Mensi P, Schenone G (1984) Biochemical and ultrastructural effects of nitrite on rainbow trout: liver hypoxia at the root of the acute toxicity mechanism. Environ Res 34: 135-154.

50. Scarano G, Saroglia MG, Gray RH, Tibaldi E (1984) Hematological responses of sea bass Dicentrarchus labrax to sublethal nitrite exposure. Transactions of the American Fisheries Society 113: 360-364.

51. Michael MI, Hilmy AM, El-Domiaty NA, Wershana K(1987) Serum transaminases activity and histopathological changes in Clarias lazera chronically exposed to nitrite. Comp Biochem Physiol 86: 255-262.

52. Jensen FB (1990) Nitrite and red cell function in carp: control factors for nitrite entry, membrane potassium ion permeation, oxygen affinity and methaemoglobin formation. J Exper Biol 152: 149-166.

53. Knudsen PK, Jensen FB (1997) Recovery from nitrite-induced methaemoglobinemia and potassium balance disturbance in carp. Fish Physiology and Biochemistry 16: 1-10.

54. Vedel NE, Korsgaard B, Jensen FB (1998) Isolated and combined exposure to ammonia and nitrite in rainbow trout (Oncorhynchus mykiss): effects on electrolyte status, blood respiratory properties and brain glutamine/glutamate concentrations. Aquatic Toxicology 41: 325-342.

55. Wlasow T, Dabrowska H (1990) Haematology of carp in acute intoxication with ammonia. Polskie Archiwum Hydrobiologii 37: 419-428.

56. Svobodova Z, Vykusova B, Machova J (1994) The effects of pollutants on selected haematological and biochemical parameters in fish. In: Muller R, Lloyd $\mathrm{R}$ edn. Sublethal and Chronic Effects of Pollutants on Freshwater Fish. FAO Fishing news books, Oxford 39-52.

57. Nussey G, van Vuren JHJ, du Preez HH (2002) The effect of copper and zinc at neutral and acidic $\mathrm{pH}$ on the general haematology and osmoregulation of Oreochromis mossambicus. African Journal of Aquatic Sciences 27: 61-84.

58. Tavares-Dias M, Oliveira SR (2009) A review of the blood coagulation system of fish. Brazilian Journal of Biosciences 7: 205-224.

59. Blaxhall PC (1972) The haematological assessment of the health of freshwater fish: A review of selected literature. Journal of Fish Biology 4: 593-604.

60. Pavlidis M, Futter WC, Katharios P, Dianach $P$ (2007) Blood cell profile of six Mediterranean fish species. Journal of Applied Ichthyology 23: 70-73.

61. Saunders DC (1968) Variations in thrombocytes and small lymphocytes found in circulating blood of marine fishes. Transactions of the American Microscopical Society 87: 39-43.

62. Jensen FB, Andersen NA, Heisler N (1987) Effect of nitrite exposure on blood respiratory properties, acid-base and electrolyte regulation in the carp (Cyprinus carpio). Journal of Comp Physiol 157: 533-541.

63. Stormer J, Jensen FB, Rankin JC (1996) Uptake of nitrite, nitrate and bromide in rainbow trout, Onchorhynchus mykiss: effects on ionic balance. Canadian Journal of Fisheries and Aquatic Sciences 53: 1943-1950.

64. Woo NYS, Chiu SF (1996) Metabolic and osmoregulatory responses of the Sea Bass Lates calcarifer to nitrite exposure. Environmental Toxicology and Water Quality 12: 257-264

65. Laurent P, Perry SF (1991) Environmental effects on fish gill morphology. Physiology and Zoology 64: 4-25.

66. Bullock GL (1972) Studies on selected myxobacteria pathogenic for fishes and 
Citation: Patrick Saoud I, Naamani S, Ghanawi J, Nasser N (2014) Effects of Acute and Chronic Nitrite Exposure on Rabbitfish Siganus rivulatus Growth, Hematological Parameters, and Gill Histology. J Aquac Res Development 5: 263. doi:10.4172/2155-9546.1000263

on bacterial gill disease in hatchery-reared salmonids. US Bureau of Sport Fisheries and Wildlife, Technical Paper 60

67. Larmoyeaux JD, Piper RG (1973) Effects of water reuse on rainbow trout in hatcheries. Progressive Fish-Culturist 35: 2-8.

68. Takashima F, Hibiya T (1995) An atlas of fish histology. Normal and pathological features, 2nd edn., Kodansha Ltd., Tokyo.

69. Karan V, Vitorovic S, Tutundzic V, Poleksic V (1998) Functional enzymes activity and gill histology of carp after copper sulfate exposure and recovery. Ecotoxicol Environ Saf 40: 49-55.

70. De Boeck G, Grosell M, Wood C (2001) Sensitivity of the spiny dogfish Squalus acanthias to waterborne silver exposure. Aquat Toxicol 54: 261-275.

71. Peters G, Hoffmann R, Klinger $H$ (1984) Environmental induced gill disease of cultured rainbow trout (Salmo gairdner). Aquaculture 38: 105-126.

72. Alazemi BM, Lewis JW, Andrews EB (1996) Gill damage in the freshwater fish
Gnathonemus petersii (family: Mormyridae) exposed to selected pollutants: an ultrastructural study. Environmental Technology 17: 225-238.

73. Brown DA, McLeay DJ (1975) Effect of nitrite on methemoglobin and tota hemoglobin of juvenile rainbow trout. The Progressive Fish-Culturist 37: 36-38.

74. Cameron JN (1971) Methemoglobin in erythrocytes of rainbow trout. Comparative Biochemistry and Physiology 40: 743-749.

75. Huey DW, Beitinger TL (1980) Hematological responses of larval Rana catesbeiana to sublethal nitrite exposures. Bulletin of Environmenta Contamination and Toxicology 25: 574-577.

76. Smith CE, Williams WG (1974) Experimental nitrite toxicity in rainbow trout and Chinook salmon. Transactions of the American Fisheries Society 103: 389-390.

77. Crawford RE, Allen GH (1977) Seawater inhibition of nitrite toxicity to chinook salmon. Transactions of the American Fisheries Society 106: 105-109. 